\title{
Ekologinen luontoyrittäjyys Suomessa
}

Matti Luostarinen ja Paula Vanhamäki

Maa-ja elintarviketalouden tutkimuskeskus (MTT), 31600 Jokioinen, matti.luostarinen ${ }^{\circ} \mathrm{mtt} . \mathrm{fi}$

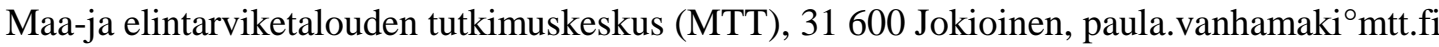

\section{Johdanto}

Luontoyrittäjyydellä (nature-based entrepreneurship) tarkoitetaan luonnonantimiin ja luonnon tarjoamiin elämyksiin perustuvaa ympäristövastuullista yrittäjyyttä (Rutanen \& Luostarinen 2000). Luontoyrittäjyydessä painotetaan erityisesti luonnon aineettomia arvoja ja uusiutuvien luonnonvarojen ekokestävää käyttöä. Toiminnassa yrittäjät hyödyntävät uusiutumattomia luonnonvaroja mahdollisimman vähän luontoa kuluttaen ja hakien innovatiivisia toimintamalleja. Luontoyrittäjyys voidaan jakaa seuraaviin sektoreihin (Rutanen \& Luostarinen 2000):

1) Luonnon tarjoamiin mahdollisuuksiin perustuva vastuullinen matkailu elämyspalveluineen (mm. luonto-, elämys- ja metsästysmatkailu)

2) Puun ja puusta saatavien tuotteiden ympäristövastuullinen jalostaminen muissa kuin suuressa ja keskisuuressa teollisuudessa

3) Luonnonmarjojen, -sieninen ja -yrttien yms. keruutuotteiden hyödyntäminen sekä luonnonkasveja hyödyntävä viherrakentaminen

4) Riistan, kalojen ja rapujen hyödyntäminen

5) Turpeen ja kiven sekä muiden maaperäainesten pienimuotoinen ja kestävän käytön mukainen hyödyntäminen

6) Vesivarojen sekä lumen ja jään hyödyntäminen

7) Muut luontoon tukeutuvat palvelut (mm. ympäristön siistiminen ja raivaus, virkistyspalvelut, luontoon liittyvä sisältötuotanto)

Luonnon antimia ja elämyksiä hyödyntävä yritystoiminta on usein pienimuotoista ja maaseudulla, etäällä taajamista tai kasvukeskuksista tapahtuvaa. Usein toimintaa kuvaavat termit käsityömäisyys, yksilöllisyys, paikallisuus ja kotimaisuus. Perinteitä vaalivista arvoista huolimatta toimialalle ja sen tuhansiin yrityksiin kohdistuu suuria odotuksia tekniikan uusista innovaatioista, ekokuluttajien kasvavista vaatimuksista sekä toimialan nopeasta kasvusta osana alueellisia, kansallisia ja kansainvälisiä kehitysohjelmia. Suomessa nämä ohjelmat ovat liittyneet läheisesti a) innovaatio-ohjelmiin, b) verkosto- ja klusteriohjelmiin, c) kestävän kehityksen ekologisiin, taloudellisiin ja sosiokulttuurisiin ohjelmiin sekä d) yritys- ja aluetalouden ympäristöohjelmiin. MTT:n sisällä yhtymäkohdat muuhun tutkimukseen ovat eko- ja ympäristöarvojen tuotteistamisessa (Rural life design), maa- ja elintarviketalouden ympäristönhallinnassa ja elinkaaritutkimuksessa, ERNIE (European Rivers Network) -ohjelmassa, Indikaattoritutkimuksessa (SUSAGRI) sekä materiaalivirtojen ekotehokkuuden tutkimuksessa.

Toimialan kehittämisen ongelmia ovat sen hajanaisuus sekä kehitystyössä tarvittavan tiedon vähyys ja pirstaleisuus. Toimialalla on paikallisia ja alueellisia verkostoja mutta yhteinen kansallinen järjestäytyminen, edunvalvonta ja imago tuotteineen (tuoteperheineen) puuttuu. Ensimmäisen kansallisen organisaation perustaminen käynnistettiin vuonna 2000 nyt käsiteltävän tutkimusprosessin toimesta (Rutanen \& Luostarinen 2000). Lisäksi eri toimijoita ei vielä yhdistä yhteisen ekologisen, taloudellisen ja sosiaalisen kestävän kehityksen mittaava indikaattoreiden systemaattinen ympäristöohjelma. Niinpä mikä tahansa yrittäjyys on pyrkimässä kohti ns. ekologista yrittäjyyttä (eco-entrepreneurship), jossa kestävää kehitystä on lähestytty mm. WBCSD: n (World Business Council for Sustainable Development) julkaiseman seitsemän kohdan ohjelmalla (1997) sekä monikansallisina ohjelmina mm. YK:n, OECD:n ja WTO:n toimesta. Maaseudun yrittäjyyden kohdalla ohjelmissa mainitaan usein ongelmalliset innovaatioympäristöt, ekotehokkuus, verkostoitumisen tarve, asiakaslähtöisyys, ohjauskeinot ja hallintajärjestelmät sekä kuluttajia palvelevat yritysten laatu- ja ympäristöjärjestelmät, luonnonvaran yleinen arvoperusta sekä lopulta maaseuturakenteen sosiaalisen kestävyyden ideologia. Laajempana käsitteenä "sustainable business" on jo mm. yliopistojen koulutusohjelmissa.

Vuonna 1999 käynnistettiin ympäristöklusterin tutkimusohjelma MTT:n koordinoimana yhteistyössä Helsingin yliopiston Maaseudun tutkimus ja koulutuskeskuksen (MAKES) Seinäjoen yksikön kanssa tavoitteena selvittää 
1) Luontoyrittäjyyden sisältö ja käsite sekä alueelliset erityispiirteet ja innovaatioaste

2) Alueellisten verkosto-organisaatioiden toimintatapa ja kehittyneisyys

3) Toiminnassa mukana olevat organisaatiot, tutkimuslaitokset, kouluttajat, neuvojat ja rahoitusinstrumentit

4) Osaamisen kärkialueet ja ongelmallisimmat pullonkaulat

5) Alueellisten (maakunnallisten) verkostojen sekä kansallisen verkosto-organisaation tarve ja kehittämismahdollisuus

6) Fokusoidut tehtävät kehitystyössä sekä missio tulevaisuudelle

Jatko-ohjelmassa vuonna 2001 käynnistettiin yhteisen organisaation rakentaminen sekä luontoyrittäjyysverkoston kokoaminen internetin sisällä. Tutkimusohjelmia syvennettiin siten että nyt käsillä oleva tutkimus pyrki selvittämään

1) Kuluttajan näkökulman, arvot ja asenteet luontoyrittäjyyteen sekä kulutuksen mahdollisen segmentoitumisen (kuluttajaklusterit)

2) Yrittäjien ympäristönäkökulman ja innovaatioluokituksen verkostoitumisessa (yrittäjäklusterit)

3) Lainsäätäjän ja kansanedustajan ympäristösidoksen ja käsityksen luontoyrittäjyyden kehittämisestä

\section{Aineisto ja menetelmät}

Tutkimusaineistona käytettiin kyselytutkimuksen tuottamaa materiaalia sekä aiheeseen liittyvää kirjallisuutta, joita analysoitiin kvantifioivan kvalitatiivisen analyysin (Eskola \& Suoranta 1999) keinoin. Kyselyn ensimmäisessä vastaajaryhmässä $(n=2000)$ olivat mukana satunnaisotannalla kaikki suomalaiset kuluttajat ja toisessa suomalaiset kansanedustajat $(n=200)$. Kolmannessa mukaan oli haettu luontoyrittäjiä $(n=282)$. Pääosin huhtikuussa 2001 suoritettujen kyselyjen palautusprosentit vaihtelivat 20-25 välillä ja alueellisesti parhaat tulokset saatiin taajama-alueilta, etenkin pääkaupunkiseudulta, joissa ylitettiin reilusti $30 \%$ :n raja. Kuluttajakyselyssä tyyppivastaaja oli keski-ikäinen, akateeminen, naimisissa oleva nainen juuri pääkaupunkisedulta tai maakuntakeskuksesta. Yrittäjät taas olivat maalla asuvia pääosin miehiä ja selvästi heikommin koulutettuja kuin kuluttajat. Yrittäjien ja kuluttajien sosioekonominen tausta oli hyvin erilainen ja myös asuinpaikkamieltymykset erosivat.

Analyyseissä käytettiin runsaasti ns. monimuuttujamenetelmiä. Tällaisia olivat etenkin korrelaatiopohjaiset faktori- ja pääkomponenttianalyysit sekä havainnoittain käytetyt faktori- ja pääkomponenttipisteet sekä näiden ryhmittely- ja klusterianalyysit. Menetelmillä pyrittiin selvittämään useiden muuttujien (=vastausten) yhteisvaihtelua harvojen, mieluummin toisistaan riippumattomien, hypoteettisten muuttujien (=faktoreiden) avulla.

Prosessikuvauksessa ei ainoastaan haluttu tunnistaa ja nimetä faktorit vaan samalla haettiin niiden synnyn takana olevia ilmiöitä. Faktoreiden latausten tulkinnan ohella niitä voitiin verrata jo aiemmin suoritettuihin vastaaviin faktorointeihin (kirjallisuus ks. Luostarinen \& Vanhamäki 2001). Tällainen tarkastelu on paikallaan etenkin faktoriekologisessa tutkimuksessa, jossa mukana ei ole niitä yleisiä validiteettiongelmia, jotka usein vaikeuttavat tämänkaltaisen tarkastelun suorittamista. Menetelmä sopii hyvin sekä hypoteettiseen ja deduktiiviseen työskentelyyn perinteisemmän induktiivisen empirian tulkinnan ohella tiivistäen mahdollisia uusia suuren kyselyaineiston perusulottuvuuksia. Tuloksia arvioitaessa on syytä korostaa, että faktoriratkaisut tuottavat aina määrättömän määrän ratkaisuja ja että tutkijan on itse kyettävä antamaan riittävät lisäehdot haettaessa lopulta käytettävää ratkaisua. Käytännössä kyseessä on faktoriakseleiden kiertäminen (=rotatointi) faktoriavaruudessa. Rotaatiokriteereistä ehkä parhaiten tunnettu on Kaiserin kehittämä varimax -menetelmä, jossa maksimoitava funktio on latausten neliöiden varianssi.

Ryhmittely- ja klusterianalyyseilla haettiin lisäinformaatiota erityisesti syntyneiden ryhmien (klustereiden) sisäisen informaation purkamiseen. Lisäksi analyysejä käytettiin niille tyypillisellä tavalla typologioiden muodostamiseen. Usein rinnalla käytetään transformaatioanalyysiä, jolloin päästään eri aikoina suoritettujen faktoriratkaisujen vertailuun. Analyysitapa on lähellä ehkä paremmin tunnettua erotteluanalyysiä (=diskriminaatioanalyysi). Niinpä klustereiden (ryhmien) välisiä eroja mitattaessa erotteluanalyysi toimii tasoerojen (=keskiarvojen) pohjalta, kun taas transformaatioanalyysin transformoituminen kertoo pikemminkin rakenne-eroista (=kovarianssierot) (menetelmistä esim. Luostarinen 1991). Etenkin spatiaalisten erojen tulkinnassa ja selittämisen syventämisessä on mahdollista käyttăä myös residuaalimatriiseja, jotka kuvaavat poikkeaman transformoitumisen ja ovat siten alueellisessa vertailussa käytettyjä. Kartoitettunahan ne kertovat poikkeaman alueellisen vaihtelun jokaisen havainnon (yrityksen, kuluttajan, kansanedustajan jne.) kohdalla erikseen. Kuten poikkeamat (=residuaalit) yleensä nämä saattavat kertoa hyvinkin merkittävistä sellaisista löydöksistä, 
joiden suuntaan analysointia on syytä jatkaa. Tässä tapauksessa aineiston rakenne johti transformaatioanalyysiin faktoripisteistä.

\section{Tulokset ja tulosten tarkastelu}

Tutkimuksen mukaan suomalaiset kuluttajat ovat erittäin ympäristötietoisia ja ekologinen luontoyrittäjyys nähdään merkittävänä kehitettävänä toimialana. Sekä alan markkinointia että tuotevalikoimaa kuuluisi vastaajien mukaan lisätä. Valtaosa ( yli 60 \%) on lisäksi valmis maksamaan hieman korkeampaa hintaa sertifioidusta, laatuvarmistetusta, ekologisesta tuotteesta, joista parhaiten tunnetaan elintarvikkeet. Yli $90 \%$ ilmoitti jo nyt käyttävänsä päivittäin ekotuotteita ja yli $70 \%$ näistä elintarvikkeita. Ympäristömieltymysten ja -identiteetin kohdalla vastaajat näyttäisivät tunnistavan paremmin yhteisön ja sen vaatiman "ympäristön" kuin oman sisäisen, piiloviestintäisen ympäristötietoisuuden. Niinpä kuluttajan omasta ympäristöstään ja ekologisesta käyttäytymisestään antama kuva on tuotteiden ja palvelujen hankinnassa kommunikaatioyhteisön tuottamana todempi ja välittyy myös tutkimuksessa voimakkaampana kuin mitä yksilön oma tarpeentyydytys tai ympäristöjärjestelmä antaisi odottaa. Näin syntyy "vinoja" vastausjakaumia, joita voidaan selittää myös esim. kognitiivisen dissonanssin teorialla. Tällä havainnolla on erityisen suuri merkitys tuotettaessa luontoyrittäjyyden immateriaalisia, sepitteellisiä tuotteita tai palveluja.

Ympäristömieltymysten ja -identiteetin sekä ideaalimaiseman kuvauksessa kansanedustajien ympäristösymboliikka on kuluttajakyselyä rikkaampi, joskin erot eri kuluttajaryhmien välillä ovat suuria. Kuluttajien ja kansanedustajien ideaalimaisema liittyy miltei poikkeuksetta maaseutuympäristöön. Lähes $90 \%: 11$ vastaajista luonnolla ja maaseudulla on juuri juurten kautta syntyvää, syvempää tunnepitoista merkitystä. Kansanedustajien kohdalla identifioituminen maaseutuun ja sen sekä luonnon- että kulttuuriympäristöön on jopa muista vastaajia voimakkaampi. Käsitys ekotuotteista ja niiden kulutuksesta on kuitenkin hieman kriittisempi.

\section{Kuluttajafaktori ja -klusterit}

Faktoriratkaisu tuotti neljä pääulottuvuutta, joista tärkein oli hyvin myönteisten ympäristöasenteiden perusfaktori (faktori 1). Tästä erottui hieman kriittisempi, kaupunkimaiseen asumiseen jo juurtuneen toisen polven kaupunkilaisen ympäristöfaktori (faktori II). Kolmas faktori irtautuu ensimmäisestä ja on lähinnä viimeisimmän aallon mukana pääkaupunkiseudulle tai maakuntakeskuksiin muuttaneiden ja monia tunnearvoja korostavien faktori. Neljäs erottuu tästä lähinnä aiemmin tapahtuneen muuton seurauksena (suuret ikäluokat) ja tyytymättömyys nykyisen asuinympäristöön voidaan kertoa edellistä ryhmää "objektiivisemmin". Etäsyyttä muuttoon on jo riittävästi. Tyytymättömyys ja yleisen asenneilmaston kriittisyys kasvaa siirryttäessä ensimmäisestä faktorista neljänteen. Kansanedustajien vastaukset tuottavat odotetusti samat faktorit kuin kuluttajakyselyssä.

Lähes $80 \%$ ekoyrittäjien asiakkaista näyttäisi asuvan kaupungeissa (maakuntakeskuksissa) ja lähes puolet pääkaupunkiseudulla. Vastaajista $60 \%$ on korkeasti koulutettuja, keski-ikäisiä naisia ja kaukana siitä kulttuuriympäristöstä, jossa eko- ja luontoyrittäjät maaseutuyrittäjinä elävät ja usein markkinansa hakevat. Klusterianalyyseissä kuluttajat ryhmittyivät kymmeneksi keskenään homogeeniseksi ryhmäksi, joiden pääakselisuunnat faktoriratkaisuissa kulkivat joko faktori yhdestä kahteen tai kolmannesta neljänteen. Näistä edellinen näyttäisi liittyvän fyysiseen, sosiaaliseen ja kulttuuriseen identifikaatioon ja sen muutokseen

sekä jälkimmäinen normijärjestelmien muuttumiseen (moraali, etiikka, ekologia, estetiikka, empatia). Ryhmien nimeämisessä on käytetty modernin sosiologian tai kulttuuriantropologian antamia viitteitä soveltuvilta osin. Toisiaan lähinnä olevat ryhmät on yhdistetty faktoriakseleiden muodostamassa nelikentässä käyttäen nimeämisessä Christopher Laschin, Charles Bauderlairen ja Zygmund Baumanin postmodernin ihmisen ja elämänstrategian kuvaamista joko kuljeskelijan (flaneeraaja), turistin, kulkurin tai pelurin silmin (kirjallisuus ja tyyppien kuvaus ks. Luostarinen \& Vanhamäki 2001). Kuvassa 1 nämä tyypit on siirretty oikeille paikoilleen faktoriakselistolla ja kuvattu muutamalla sanalla ja streotyyppeinä. On luonnollista että kuluttajaryhmät eivät koskaan esiinny puhtaina vaan mukana on aina välittäviä tyyppejä ja jokaisessa kuluttajassa hieman kaikkienkin ryhmien tunnuspiirteitä.

Käsite flaneeraaja on alun perin Charles Bauderlairelta, joka kutsui näin Constantin Guyn maalaamat kaupungin katunäkymät "kuljeskelijan" silmin sellaisina, jossa postmodernin elämän näkökulma paljastui juuri tyhjän kuljeskelun ja kuluttajan kokemusten kautta katutasossa. Tässä kuluttajaryhmässä tärkeintä on se, miltä ympäristö ja maaseutu näyttävät. Kokemus on aina lyhytkestoinen ja episodimainen ja vailla menneisyyttä tai juuria 
maaseudulle. Maailma muistuttaa supermarkettia, jonka erinomaisuutta ei ole syytä kritisoida. Yhden asian ilmiöt eivät kasva ja nivoudu toinen toistaan tukien, vahvistaen ja laajentaen. Ympäristönäkemys on pirstaleinen, katkelmallinen kapea-alainen ja pintapuolinen. Tyhä supermarket täytetään katkelmallisilla mielihyvän, kiinnostuksen ja jännityksen palasilla. Suomessa ilmiö näyttäisi liittyvän viimeisimpään postmodernisaatioon, yhteisöllisyyden lopulliseen katoamiseen sekä uusimpaan kaupunkilaistumiseen, kaupungistumiseen globalisaation ja 1990-luvun hengessä.

Toinen ryhmä eroaa edellisestä vain hieman. Siinä ympäristönäkemykset ovat todempia ja kokemukset muuttuvat "ikään kuin" maailmasta "miltä näyttää" maailmaan. "Miltä näyttää" elämästä ja kokemuksesta on tullut todellinen kokemus, jota ympäristö, luonnonvarat ja ekologia yhdistävät. Näillä ihmisillä on runsaasti vapa-aikaa ja kuljeskelusta on tullut elämäntapa. Ostos- ja kulutuskäyttäytymisestä on tullut myös maaseudulla kauppakujien ja markettien ostoskäyttäytymistä. Niinpä yrittäjä ("sustainable business") joutuu rakentamaan "saarekkeita" mittatilaustöinä juuri tälle kuluttajasegmentille. Nämä saarekkeet ovat irrallisia tulevasta ja menneestä, mutta niissä voi kuvitella olevansa itse ohjaajana, luontotapahtuman tai ympäristön kohtaamisen vaikuttajana silloinkin, kun kuljeskelija on kaiken aikaa ohjatussa toiminnassa mukana.

Ryhmästä eroaa äärimmilleen puhtaaksi viljelty joukko "kuvaruutu" -ihmisiä, joiden siirtyminen omaan ryhmään näyttäisi selittyvän Henning Benchin "telecity" pelkistyksillä. Ympäristönäkemys alkaa olla lähellä vahvaa kokemusta kuvaruudun pinnasta mielikuvitukseen liitettynä. Luontokokemukselta tai ekotuotteelta vaaditaan paljon enemmän kuin edellisissä ryhmissä ja fantasia on sen vahvin yrittäjävaltti. Äärimmäisen vapauden tunnetta ohjaa vain kuvaruutu, keskittynyt tarkkailu, jossa tietokoneen näyttö tai televisio ovat neutraaleja. Luontosuhteesta on tullut hyvin yksityinen alue, jossa ihminen kohtaa ostogalleriassa luontokokemuksensa ikään kuin individualisti uskonnollisen elämyksensä.

Neljäs kuluttajaryhmä syntyy täydellisestä juurettomuudesta neljännen faktorin ääripäähän. Nämä ihmiset eivät ole koskaan paikallaan tai juurillaan, vaan hakevat matkasuunnitelmansa ja reittinsä pala palalta tai eräänlaisen post-traditionaalisen kaaoksen kautta. "Kulkurin" maailmaa luonnehtii ulkopuolisuuden vaatimus ja sen vaaliminen. Kaikkea pidetään avoimena ja vaihtoehtoja on runsaasti. Saapumisen muisto on tuore vielä vuosienkin jälkeen. On epävarmuutta työpaikasta, vanhan tiedon tai taidon arvosta, turvallisesta kohdasta johon asettua ja samaistua. Vieraantuminen yhteisöllisyydestä, fyysisestä ympäristöstä ja sosiaalisista siteistä on tapahtunut tavalla, jossa ei ole enää nostalgista kaipuuta. Agraariin tai jälkiteolliseen kulttuuriin ei ole edes alitajuista kosketusta. Uusi mediakulttuuri ja globaali paikattomuus on osa tämän ryhmän jatkuvaa kasvamista.

Kun kulkuri liikkuu lähinnä erilaisten voimien työntämänä, "turisti" liikkuu uskoen toimintansa olevan tavoitteellista. Turisti viettää kesänsä tien päällä ja kaikki ympäristössä on säyseää ja kesytettävää. Ekoyrittäjältä haetaan elämyksiä, jotka ovat silmiinpistävän erikoisia mutta samalla myös kertakäyttötuotteita tai -kokemuksia. Turisti ei hae muistoja vaan vaarattomia hetkiä ilman muistoon sitoutumista. Maaseutuun ja sen nostalgiaan liittyy vanhan paikkaidentiteetin "tuska" sekä halu säilyttää tämä muisto; hakea kadotettua ja kokea ohjattuna turistilaumana tai mieluiten yksin kokemuksensa kautta nauttien ja sen myös ymmärtäen. Turisti hakee aina turvapaikkaa ja koti on myös osa tätä samaa "seikkailijan" turvapakettia. Ekokokemuksen tai tuotteen on oltava suolla tai metsässä "järkytys" turvallisessa paketissa. Jonathan Swartzin turistilla on kahdenlaista ikävää. Toinen syntyy nostalgiasta, menetetyistä juurista ja toinen kaipuusta kotiin. Osalle (suuret ikäluokat) turistimatkasta on tullut pysyvä, jolle koti on yhtäl̈llä huonon identiteetin korvike jossakin muualla kuin lähtöalueella, kaukana 1960-luvulla. Menetetty identiteetti tekee kotiunelmasta joskus toteutuvan mahdollisuuden kaukana horisontissa ja aina maaseudulla. Näin nykyinen koti on paikka, joka on samaan aikaan turvallinen ja pelottava sitoja; todellisen unelman hävittävä vankila. Tämän paradoksaalin elämän sisältö on siirtynyt lapsin, jotka elävät peliteorioiden, markkinatorien ja konfliktien turvattomassa maailmassa.

Pelaajan maailma on riskien maailmaa, jossa mukana ovat kohtalo, johdatus, intuitio ja oveluus. Näissä toisen ja neljännen faktorin ääripään ryhmissä markkinatorien maailma on pelaajalle hieman armollisempi kuin jatkuvan sotatantereen maailma. Molemmissa on kuitenkin puutetta rakkaudesta, rahasta, arvonannosta, moraalista jne. ja kaikesta käydään hillitöntä kamppailua. Maailma on peli, jossa pelaajat selviävät omalla oveluudellaan - kaukonäköisellä tai virheellisellä. Maailma on pirstottu pelien osiin ja kustakin tehdään oma sisäinen merkitysalueensa, kustakin omaan itseensä sidottu itseriittoinen peli. Ekoyrittäjä on mukana pelissä, jossa ympäristö ja luonto on vain yksi merkitysalueensa. Ei kaiken toiminnan läpäisevä ja kattava elinympäristö vaan vain pieni osa pelien maailmaa. Jos yrittäjä kieltää pelaajan maailmankuvan, hänet suljetaan pois ja pelkona on eristäminen tai joutuminen vielä armottomampaan peliin. Ympäristön ja luonnon näkökulmasta ongelmallista on pelaajan moraalin puutuminen ja korvautuminen pelin säännöillä, joita kukaan ei ole kirjoittanut. Näin myös 
ekologisesta ja eettisestä tulee pelaajalle lopulta lähinnä vain joko turvakilpi tai tavoite voittaa siinä kilpailussa, jossa ympäristön ja luonnonvarojen kestävä kehitys ovat oletettuja pelivälineitä ja tapa menestyä kilpailussa ("sustainable business"). Kun globaalissa ympäristössä vastassa on koko maailma, ei lopultakaan ole merkitystä sillä, vallitseeko siirroissa laillisuus tai laittomuus, järjestys tai kaaos ja anarkia. Tämä erottaa pelaajan maailman turistin paljon rikkaammasta, ja myös moraaliltaan kehittyneemmästä maailmasta, ja siirsi nämä kaksi ryhmää juuri ensimmäisen ja toisen faktoriulottuvuuden kohdalla kauas tosistaan. Toisen ja neljännen faktorin kohdalla ryhmät olivat vielä samassa tasossa.

\section{Yrittäjäfaktorit ja-klusterit}

Yrittäjäfaktoreista ensimmäinen ja tärkein nimettiin positiivisten odotusten ja yhteistyön perusfaktoriksi, toinen markkinatalouden ehdoilla toimivien yrittäjien faktoriksi, kolmas perusnegatiivisten, oppositiohenkisten "häirikköfaktoriksi", neljäs vihreiden perusarvojen ja yhteisvastuun faktoriksi sekä viides kovien yritysarvojen faktoriksi (Luostarinen \& Vanhamäki 2001). Erot faktoreiden välillä syntyivät lähinnä yrittäjien ympäristö- ja luontosuhteesta, moraalisesta tai eettisestä sidoksesta ekologiseen yrittäjyyteen ja sen yhteiskunnalliseen tai sosiaaliseen sisältöön ( ekologinen ja sosiaalinen kestävyys sekä yhteisvastuun käsite ), markkinakeskeisyydestä ja yritysimagon sidoksesta kestävän kehityksen käsitteistöön, innovaatioasteesta sekä yrityksen strategisista toimintaperiaatteista.

Faktoripisteiden klusteroinnissa yrittäjät ryhmittyivät kahdeksaksi homogeeniseksi klusteriksi. Kuvassa 2 nämä on paikannettu nelikenttään kahden pääakseliston mukaan joko faktoreiden I ja II suuntaisesti tai faktoreiden IV ja V suuntaisesti. Edellinen pääakselisuunta liittyy yrittäjien ympäristö- ja luontosuhteeseen sekä yritysimagoon ja sen strategisiin linjauksin (=pehmeät ja kovat arvot) sekä jälkimmäinen lähinnä yritysosaamiseen, moraaliseen ja eettiseen sidokseen sekä innovaatioluokitukseen (=sidos tuotteeseen tai kuluttajaan). Todellisuudessa faktoriakselit ovat luonnollisesti multidimensionaalisia faktoriavaruudessa ja tulokset on vain pyritty kuvissa 1 ja 2 havainnollistamaan tuomalla akselisto kaksiulotteiselle pinnalle vähentämällä samalla niiden lukumäärä viidestä kahteen (kuvassa 1 neljästä kahteen).

Ensimmäiseen kahteen ryhmään paikantuvat on nimetty perinteisiksi, konventionaalisiksi yrittäjäryhmiksi. Yrittäjyyteen liittyy luja optimismi, ekologisesta yrittäjyydestä odotetaan suurta tulevaisuuden trendiä, yhteistyötä haetaan koko toimialalle ja siihen myös sitoudutaan. IMA:n (Innovative Management Association) ja SRI:n (Stanford Research Institution) innovaatioroolien luokituksessa nämä yrittäjät sopivat parhaiten ns. klusterin organisoivaan systeemiin.

Toinen ryhmä poikkeaa edellisestä vain vähän. Ensimmäisen tavoin se asettuu lähelle ensimmäisen ja neljännen faktorin yhteistä leikkauspistettä (kuva 2). Arvomaailma on humanistis-ekologinen mutta mukana on edellistä ryhmää enemmän ns. sisäisiä yrittäjiä (intrapreneurship). Nämä vetävät omaa hanketta tai ideaa joko yrityksen sisällä tai koko yritys on yhden idean toteutusta. Joukossa on myös runsaasti ideakatalysaattoreita. Yhteisessä, innovaatiorooleja hakevassa klusterissa nämä yrittäjät paikantuvat lähinnä innovaattoriryhmään (kuva 3$)$.

Kolmas ryhmä yrittäjistä sijoittuu tiiviinä klusterina edellisten ryhmien tuntumaan (kuva 2) toisen faktorin suuntaan kuitenkin etääntyneenä. Ekokestävyyttä arvostetaan mutta arvot ovat kuitenkin edellisiä ryhmiä kovempia ja vastuu kestävästä kehityksestä on näillä "vapaamatkustajilla" vähäisempi. Joukossa on runsaasti toiminnan suuntaajia (course-keeper) eikä ryhmän yrittäjät tuota niinkään omia ideoita kuin lisäävät ideoihin kohdistuvaa kiinnostusta kuluttajissa. Innovaatiorooli yrittäjien yhteisessä verkostossa on lähinnä ns. tutkailevassa promoottorijärjestelmässä (kuva 3).

Neljäs ryhmä yrittäjiä eroaa edellisestä vain hieman neljännen faktorin suuntaan (kuva 2). Nämä "itselliset yrittäjät" toimivat miltei yksinomaan markkinatalouden pelisäännöillä ja kosketus markkinoihin, välitysagentteihin, alihankkijoihin jne. on muita ryhmiä kehittyneempi. Ympäristöarvot ja niiden merkitys imagon rakentelussa myönnetään merkittäväksi, mutta sen moraalinen painolasti on vähäinen ja "vapaamatkustajien" määrä kasvaa. Samalla kuluttajaryhmän "pelaajien" arvomaailma tulee lähemmäs toimintastrategiaa (ks. kuva 1). Yhteisessä yrittäjäverkostossa näiden yrittäjien innovaatiorooli on lähinnä teknologian ja markkinoiden portinvartijarooleja tai joissakin tapauksissa verkostomeklareina (kuva 3).

Viides ryhmä paikantuu hieman hajanaisena kirjavan toimialakentän monialayrittäjäryppäänä konventionaalisten ryhmien yläpuolelle neljännen faktorin suuntaan (kuva 2). Usein tausta on vielä perinteisessä maataloudessa ja toiminta on hapuilevaa. Nämä "tuotechampionit" uskovat omiin tuotteisiin periaatteella "hyvä tuote myy 
itsensä" ja omalle tuotteelle omistaudutaan vahvalla tunteella. Omaa ideaa viedään raivokkaasti eteenpäin, mutta kokemus yrittäjyydestä on vähäistä ja toiminta on tuotepainotteista. Yhteisessä verkostossa tai klusteritaloudessa näiden yrittäjien innovaatiorooli on lähinnä kokemusvälittäjänä, menneisyyden vanhojen ja usein jo unohdettujen ideoiden kehittelijöinä koko klusterin käyttöön

Kuudes ryhmä on lähellä kokemusvälittäjiä mutta jo "punaisen langan " löytäneenä lukuisista tuoteideoista. Taito arvioida ulkopuolisia trendejä on hyvä ja heikotkin signaalit otetaan vastaan myös kulutuksen suunnalta. Visiointitaito on kehittynyt edellisestä ryhmästä ja maatalouden merkitys on enää vain muuta yrittäjyyttä tukeva. Kansallisessa verkostossa innovaatiorooli on lähinnä systeemin arvioivassa kehittämisjärjestelmässä tai verkostomeklareina viidennen ryhmän suuntaan.

Kaksi viimeistä ryhmää koostuu avaininnovaattoreista. Tyypillistä yrittäjille on kriittisyys ja toisinajattelu, ristiriita vallitseviin megatrendeihin ja konflikti konventionaalisiin ryhmiin. Näkemykset ovat omaperäisiä ja radikaaleja, selvästi muista ryhmistä erottuvia. Kaikista yrittäjistä näihin kahteen viimeiseen klusteriin ryhmittyi noin $10 \%$ ja faktoriratkaisussa tämä määrä riitti jopa oman faktorin syntymiseen (kolmas faktori). Yrittäjien yhteisessä innovaatioroolien verkostossa näiden ryhmien merkitys on innovaattoreina tärkein. Tuekseen nämä yrittäjät kaipaavat organisaatiorakenteeseen suunnannäyttäjiä (course-keeper) tai palkitsijoita (rewarder). Maaseudulla nämä yrittäjät ovat traditionaalisessa toimintaympäristössään usein vaikeasti siedettäviä, ja seurauksena on joko katkeroituminen, väsyminen tai vetäytyminen tukijärjestelmien ja kriittisen massan puuttuessa. Kaikkein ongelmallisin on joko kontrolliorientoitunut tai pelien kyllästämä organisaatio tai yhteisö, jonka riskinsietokyky on alhainen.

\section{Johtopäätökset}

Eko- ja luontoyrittäjyys ovat käsitteinä vielä tuntemattomia mutta niiden merkitys sekä suurimpien taajamien kulutuksessa että maaseudun luonnonvarojen ja yrittäjyyden kehittämisessä on kasvava. Toimialan yrittäjyys on parhaillaan verkostoitumassa sekä alueellisesti että kansallisesti ja sen menestys perustuu mm. suurten klustereiden strategisiin linjauksiin keskittyä pääliiketoimintaansa, jolloin pienyrittäjyydelle jää enemmän tilaa. Diffuusiona ekologinen kulutus on siirtymässä globaalina ilmiönä pääkaupunkiseudulta maaseudun taajamiin ja myös itse tuotantoalueille. Ero tuotantoalueiden yrittäjien ja voimakkaasti segmentoituneiden kuluttajaryhmien välillä on sosioekonomisesti suuri ja vaikeuttaa markkinointiponnisteluja yhdessä yrittäjien pienuuden ja toiminnan käynnistysongelmien kanssa. Yhteistä strategiaa joudutaan hakemaan koskien toimialan innovaatioita, ekotehokkuutta, verkostoitumista, asiakaslähtöistä toimintaa, ohjauskeinoja ja tuoteominaisuuksia, luonnovaraarvopohjan rakentamista sekä laajempaa yhteiskunnallista ja sosiaalista kestävyyttä. Yhteinen imago ja tuotteet tai palvelut edellyttävät laajoja tutkimuksia koskien niitä indikaattoreita, jotka yhdistävät fyysisen pääoman (nature capital, material capital) inhimillisen ja sosiaaliseen pääomaan (human capital, social capital) ja näiden edellyttämiin yritysten laatu- ja ympäristöjärjestelmiin sekä laajempiin klusterin sisäisiin ympäristöohjelmiin. Organisaatioinnovaationa tämä tarkoittaa lähinnä eri innovaatiorooleihin kuuluvien yrittäjätyyppien järjestäytymistä siten, että vastaavat kuluttajaklusterit ja näiden voimakkaasti segmentoituneet osat löytävät verkostossa toisensa (kuva 3). Tässä prosessissa tutkimuksessa löydetyt kahdeksan yrittäjäklusteria muodostavat yhdessä organisaation luonnonvaroihin ja regionalismiin (paikallisuus) sidotun innovaatiojärjestelmän . Näitä innovaatiorooleja ei voida (eikä saisi) irrottaa globaalitaloudessa (klusteritaloudessa) regionalismista, mutta niiden toimintaa voidaan helpottaa globaalin kulutuksen suuntaan yhdistämällä yrittäjien innovaatioroolit toisiinsa. Näin uusi organisaatio ei ole sidottu regionalismiin (paikallisuus, rajat) tai maaseutuasumiseen. Paikallisuutta tai yhteisöllisyyttä tulisi kuitenkin vaalia.

Mallin toisen osan muodostavat kymmenen kuluttajaklusteria tai -segmenttiä. Näiden sidos regionalismiin on vähäinen tai sitä ei joissakin ryhmissä esiinny lainkaan. Kun yrittäjien toimintaa sitovat fyysinen ympäristö ja sosiokulttuuriset rakenteet, retrospektiivisuus, väärä provisionalismi (nationalismi), ekonometria jne. kuluttajasegmenttejä yhdistää pikemminkin subjektivismi, immateriaaliset arvot, fiktiiviset tunne- ja ajatuskuvat sekä tutkimuksen näkökulmasta positivismista vapaa päätöksenteko. Vaaditaan siten positivismista poikkeavaa tutkimusmetodiikkaa (introspektiivisyys). Yhteisiä ohjaavia elementtejä ovat kommunikaatiojärjestelmä ja uusin globaali informaatioteknologia. Näin kuluttajan ja yrittäjän näkökulmasta verkostoituminen ja klusterirakenteet näyttäisivät helpottavan "oikeiden" klusterin osien operoimista keskenään ja klusterin sisällä toisiaan vahvistaen. Näin oikeat kuluttajasegmentit ja yrittäjäryhmät operoivat keskenään ja tuoteominaisuudet, tuotekehittely ja markkinointitapa löytävät kullekin kysynnälle (tuotteelle, palvelulle) oikean kohteen. Verkostopalvelut ja säh- 
köinen kauppa luonnollisesti helpottavat prosessin syntyä oleellisesti ja ovat usein sen edellytys. Ei kuitenkaan sama kuin verkostotalous. Toteuttako prosessi klusteritaloudessa ns. huipputeollista kasvu-uraa vaiko ns. humanistis-ekologista kasvu-uraa riippuu lähinnä teorian tulkinnasta. Edellinen korostaa enemmän makrotaloutta ja globalisaation seurauksia, jälkimmäinen mikrotaloutta ja teorian paikallisuudesta lähtevää näkökulmaa.

\section{Kirjallisuus}

Eskola,,J. \& Suoranta,J. (1999). Johdatus laadulliseen tutkimukseen. Vastapaino. Tampere.

Luostarinen,M. (1991). Tiedonhankinta ja tutkimusmenetelmät monitieteisessä ympäristötutkimuksessa. Maatalouden tutkimuskeskus 1991, Jokioinen, p. 57.

Luostarinen,M. \& Vanhamäki, P. (2001). Ekologinen yrittäjyys. Tutkimus kuluttajien, yrittäjien ja kansanedustajien näkemyksistä ekologisen yrittäjyyden kehittämisestä Suomessa. Summary: Ecological entreprenerhip. A study on the views of consumers, Entrepreneurs and Members of Parliament on developing ecological entrepreneurship in Finland. Maa- ja elintarviketalouden tutkimuskeskus (MTT), Jokioinen. p. 165.

Rutanen,J. \& Luostarinen, M. (2000). Luontoyrittäjyys Suomessa. Alueelliset verkostot: luontoyrittäminen, matkailu- ja maaseutuklusteri -hankkeen loppuraportti. Maatalouden tutkimuskeskuksen julkaisuja, sarja B, p. 65 , liitteet 5.

WBCDS 1997. Exploring sustainable development. World Business Council for Sustainable Development. Global scenarios 2000-2050. London. 


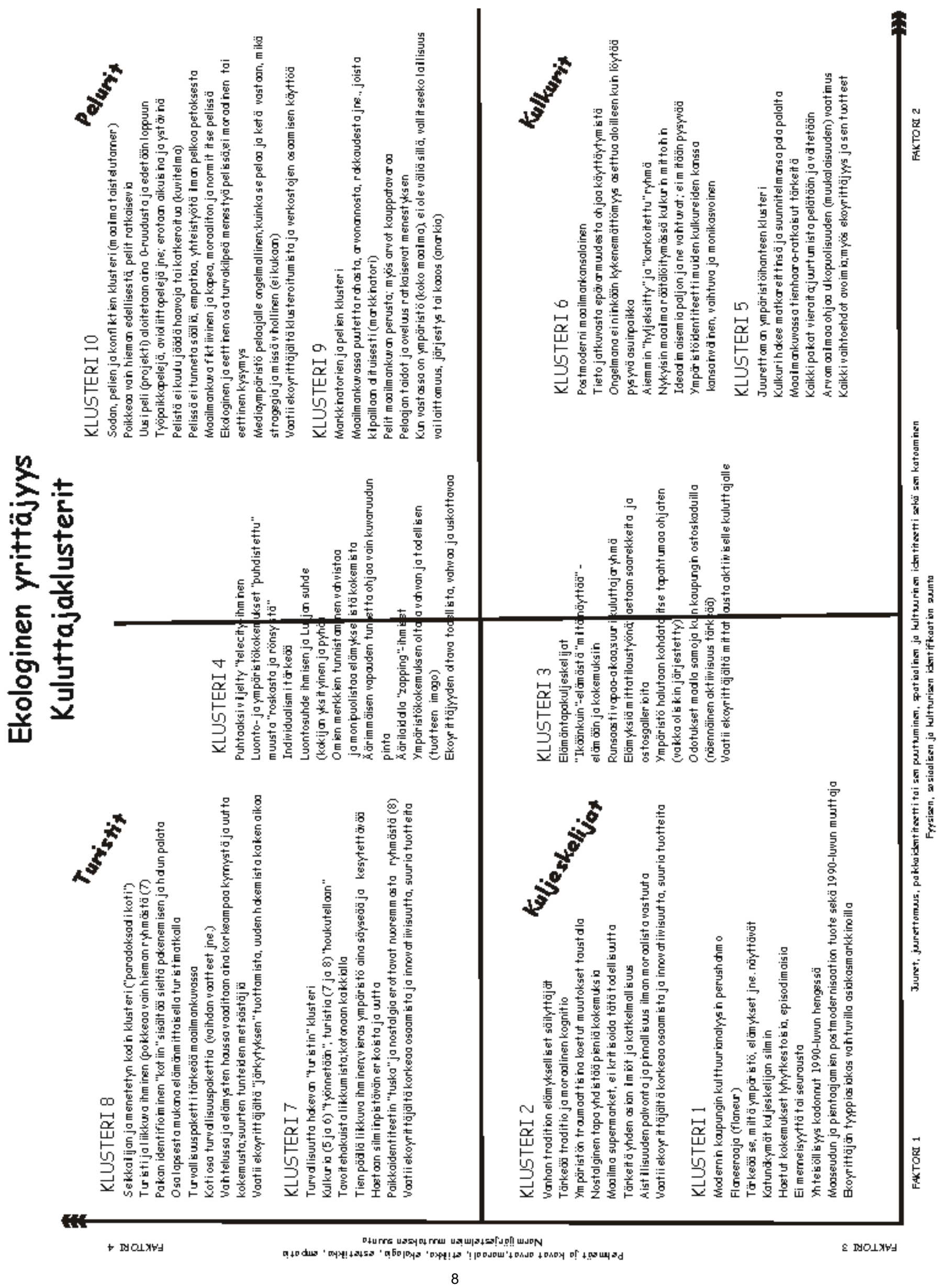



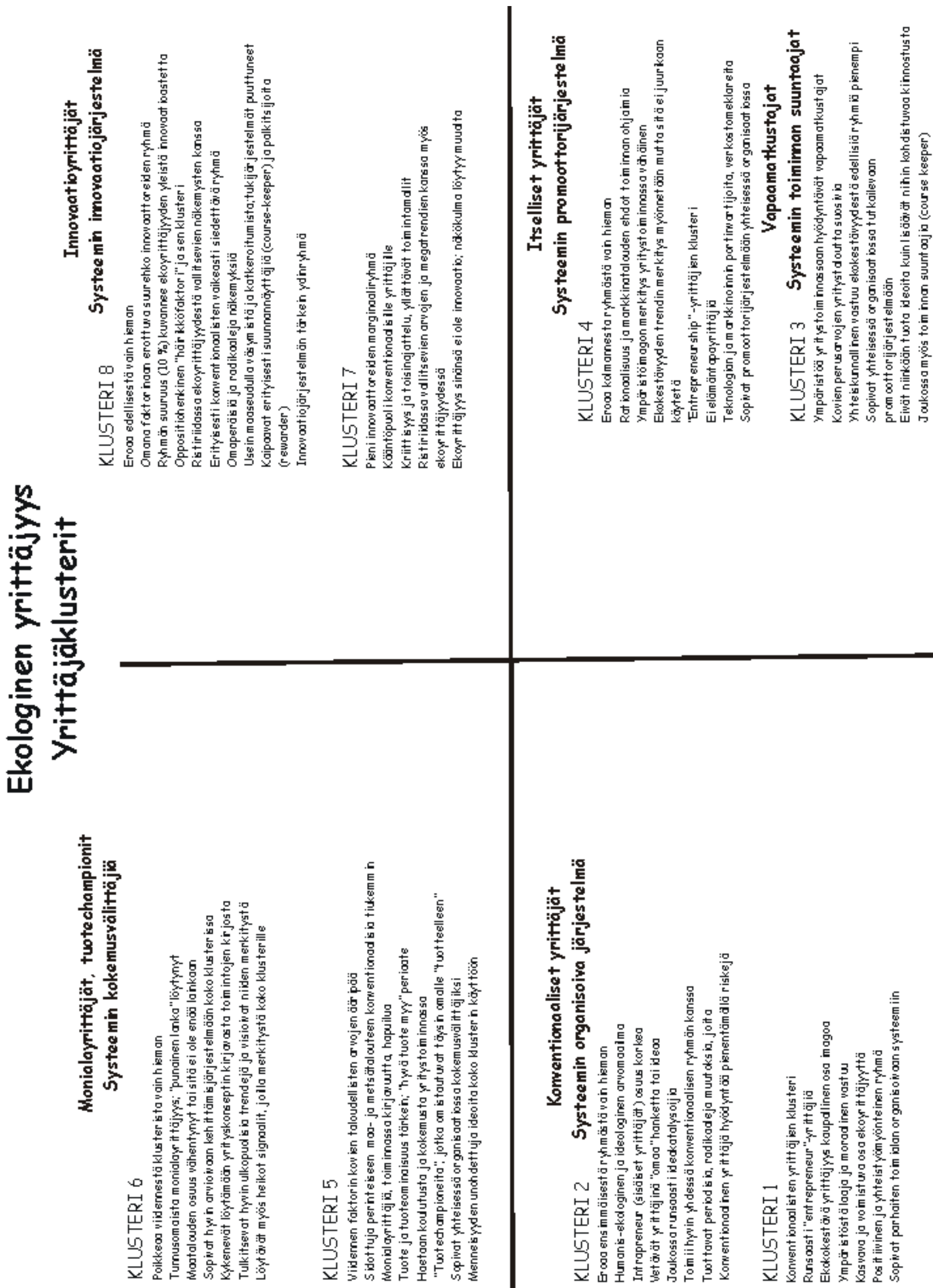


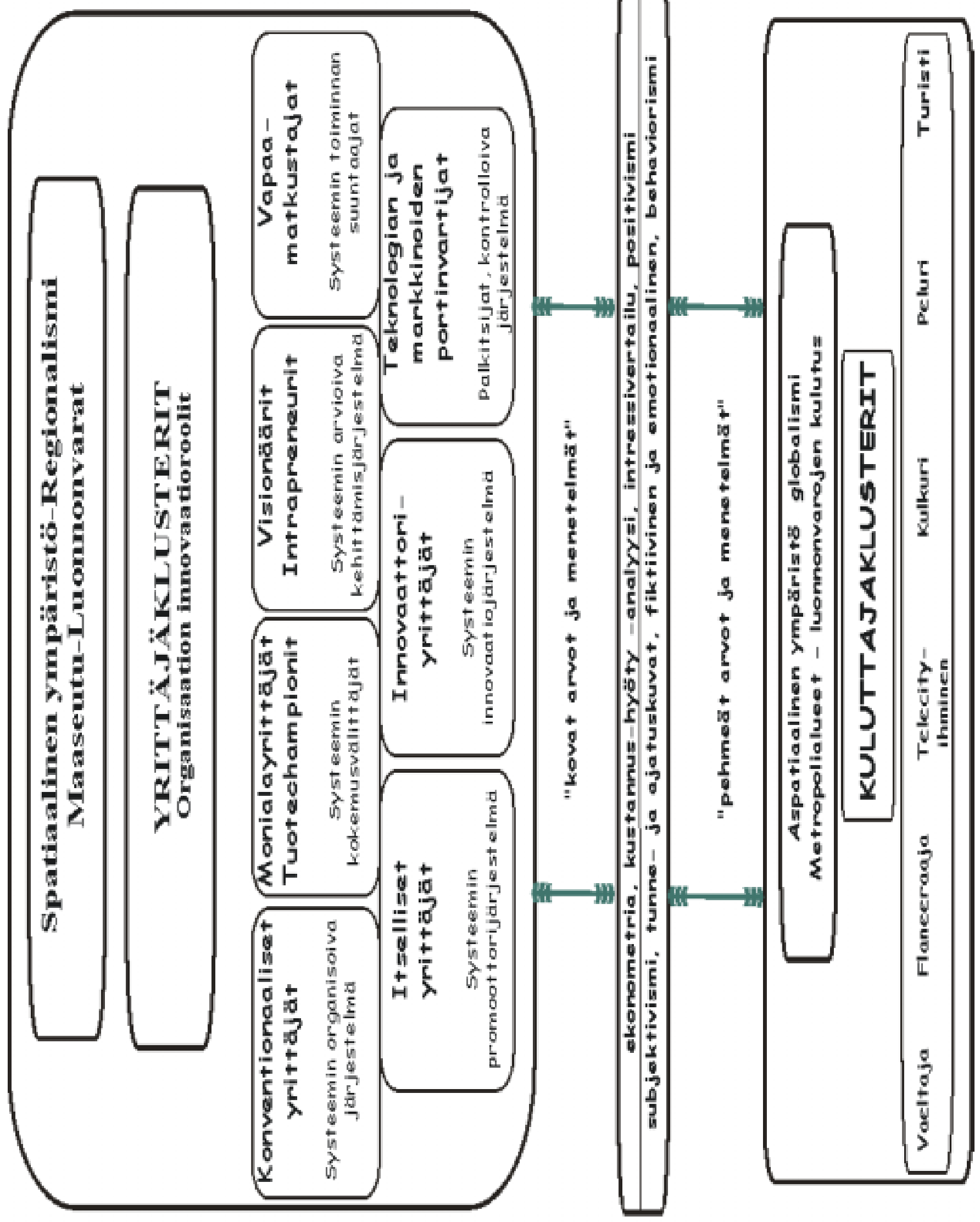

